\title{
Nitrate production and accumulation in lettuce as affected by mineral Nitrogen supply and organic fertilization ${ }^{1}$
}

\author{
Mônica L Pôrtoㅎ ; Jailson do C Alves; Adailson P de Souza²; Raunira da C Araújo²; Jandeilson A de \\ Arruda ${ }^{1}$ \\ ${ }^{1}$ UFPB-CCA, ${ }^{2}$ Dep ${ }^{\text {to. }}$ Solos Engenharia Rural, 58397-000 Areia-PB; monicalporto@ yahoo.com.br.
}

\begin{abstract}
Lettuce is one of the leading vegetables in Brazil. However, studies concerning its fertilization for the Northeastern region of the country are still scarce. This work was carried out to evaluate the effects of mineral Nitrogen supply and organic fertilization on the production and nitrate accumulation in lettuce, cultivar Elba, in the semi-arid zone of Paraíba, Brazil. A randomized block design, with four replications, was used to test five doses of cattle manure (30; $60 ; 90 ; 120$, and $\left.150 \mathrm{t} \mathrm{ha}^{-1}\right)$, five doses of $\mathrm{N}$ supplied as urea $(30 ; 60$; $90 ; 120$, and $150 \mathrm{~kg} \mathrm{ha}^{-1}$ ), and a control without fertilization. Along with mineral $\mathrm{N}$, the other nutrients were also supplied using mineral sources. No additional nutrients were supplied where organic fertilization was used. Lettuce yield was significantly higher when organic fertilization was used, compared to the mineral nutrient supply. Taking into account most of the fertilization doses recommended for growing lettuce in the Brazilian Northeastern States, $\mathrm{N}$ mineral fertilization in sandy soils with low organic matter contents can be fully replaced by organic fertilization with cattle manure. Plant total (PTY) and commercial yield (PCY) as affected by the mineral $\mathrm{N}$ supply fitted into a quadratic model, in which the doses 94.5 and $95.7 \mathrm{~kg} \mathrm{ha}^{-1}$ corresponded to respectively the highest PTY (381.9 g plant $^{-1}$ ) and PCY (321.6 g plant $^{-1}$ ). Where organic fertilization was used, PTY and PCY fitted into a linear model. Therefore, the highest PTY (523.9 g plant $^{-1}$ ) and PCY (449.48 g plant $\left.{ }^{1}\right)$ were observed at the highest manure doses. Nitrate content on roots, stems, and leaves increased linearly with Nitrogen and manure application. In roots, the nitrate content $\left(\mathrm{mg} \mathrm{kg}^{-1}\right.$ of fresh matter) reached $93.96(\mathrm{~N}$ mineral $(\mathrm{Nm})$ ) and 65.09 (organic fertilization $(\mathrm{OF})$ ); in stems, $183.45(\mathrm{Nm})$ and $98.22(\mathrm{OF})$; and in leaves, 121.98 $(\mathrm{Nm})$ and $75.62(\mathrm{OF})$. The maximum nitrate content observed in leaves was far below the risk level for human health.
\end{abstract}

Keywords: Lactuca sativa L., lettuce, cattle manure, urea, yield.

\section{RESUMO}

Produção e acúmulo de nitrato em alface em função do fornecimento de nitrogênio e da adubação orgânica

A alface é uma das hortaliças mais populares no Brasil. Porém, estudos referentes à sua adubação na região Nordeste são escassos. O objetivo deste trabalho foi avaliar a produção e o acúmulo de nitrato em alface, cultivar Elba, em função do fornecimento de nitrogênio a partir de uma fonte mineral (uréia) e da adubação orgânica. $\mathrm{O}$ delineamento experimental foi de blocos ao acaso, com quatro repetições e onze tratamentos: cinco doses de esterco bovino (30; 60; 90; 120 e $\left.150 \mathrm{t} \mathrm{ha}^{-1}\right)$, cinco doses de nitrogênio (30; 60; 90; 120 e $\left.150 \mathrm{~kg} \mathrm{ha}^{-1}\right)$ e uma testemunha sem adubação. Nos tratamentos com fornecimento mineral do nitrogênio, os demais nutrientes também foram fornecidos através de fontes minerais. Nos tratamentos em que se utilizou esterco, não houve adubação adicional. A adubação orgânica resultou em produtividade significativamente mais alta do que o fornecimento de $\mathrm{N}$ mineral. Considerando a recomendação de adubação para o cultivo de alface no Nordeste, a adubação mineral com N, em solo arenoso com baixo teor de matéria orgânica, poderia ser integralmente substituída pela adubação com esterco bovino. Para o fornecimento de $\mathrm{N}$ mineral, as produtividades total (PT) e comercial (PC) se ajustaram a um modelo quadrático. As doses 94,5 e 95,7 $\mathrm{kg} \mathrm{ha}^{-1}$ corresponderam respectivamente aos valores mais altos de PT $(381,9 \mathrm{~g}$ planta $\left.^{-1}\right)$ e PC (321,6 g planta $\left.^{-1}\right)$. Para a adubação orgânica, a resposta foi linear. Portanto, os maiores valores de PT (523,9 $\mathrm{g}$ planta $\left.^{-1}\right)$ e PC (449,48 $\left.\mathrm{g} \mathrm{plant}^{-1}\right)$ foram observados quando as doses mais altas de esterco foram utilizadas. O teor de nitrado nas raízes, caule e folhas aumentou linearmente com o fornecimento de $\mathrm{N}$ mineral e com a adubação orgânica. Nas raízes, o teor de nitrato $\left(\mathrm{mg} \mathrm{kg}^{-1}\right.$ de peso fresco) alcançou 93,96 ( $\mathrm{N}$ mineral (Nm)) e 65,09 (adubação orgânica (Org)); no caule, 183,45 (Nm) e 98,22 (Org) e, em folhas, 121,98 (Mn) e 75,62 (Org) $\mathrm{mg} \mathrm{kg}^{-1}$ de peso fresco. Os teores mais altos de nitrato observados nas folhas ficaram muito abaixo do limite de risco para saúde humana.

Palavras-chave: Lactuca sativa L., alface, esterco bovino, uréia, produtividade.

\section{(Recebido para publicação em 23 de outubro de 2007; aceito em 11 de fevereiro de 2008)}

$\mathrm{N}$ owadays there is a world-wide trend, also observed in Brazil, which consists on a growing search for healthy food, free of toxic residues, as well as environmentally friendly produced. In this context, the use of vegetables is increasingly attracting attention, mainly due to their low caloric content and high nutritional value, which significantly contributes to change the population alimentary habits.
In Paraiba, lettuce (Lactuca sativa L.) is one of the most popular vegetables. It is grown on the green belts of small, median, and large cities of the State. Intrinsic traits, such as good adaptation to different climatic conditions, short cycle, possibility of consecutive crops on a same year, regular market, among others, make lettuce one of the favorite vegetables among producers (Filgueira, 2003). It is traditionally explored on a familiar basis, which confers to lettuce, in addition to the economic importance, a high social relevance.

Lettuce is ordinarily produced in the Brazilian Northeastern region by small farmers, who use, most of the times, heavy fertilization, applying excessive doses of fertilizers, surpassing crop needs. This practice, in addition to increase costs, threatens the quality of

\footnotetext{
* Part of the M.Sc. thesis presented by the first author to the Federal University of Paraíba, Agrarian Sciences Center, Graduation Program in Agronomy, to complete the requirements for obtaining the degree of M.Sc. in Agronomy.
} 
the production and the environment. Being a leafy vegetable, lettuce responds well to Nitrogen fertilization, with a rise in yield and production uniformity, a trait with high commercial value (Filgueira, 2003). However, Nitrogen fertilization at present is a very controversial theme, since when it is excessive it can result on a decrease on quality due to nitrate accumulation. When nitrate is consumed on high amounts, it can cause serious damages to human health, such as the formation of nitrosamines, a potentially carcinogenic substance, besides metahemoglobinemy (Boink \& Speijers, 2001; Faquin \& Andrade, 2004). Therefore, appropriate $\mathrm{N}$ doses must be applied on lettuce cultivation to avoid nitrate accumulation. Another option, is growing lettuce in organic systems, which in addition to the good outcomes concerning both productive results and nutritional values (Santos et al., 2001; Villas Bôas et al., 2004; Yuri et al., 2004; Souza et al., 2005), has been showing relevant results concerning the decrease of nitrate accumulation in this vegetable (Cometti et al., 2004). Nitrate accumulation in plants grown in organic systems are presently a promising subject to develop further studies.

It can be observed that research on the effects of mineral and organic fertilization over lettuce yield and quality are relatively scarce in the Northeastern Brazilian conditions. However, studies on this subject are essential to the development and rationalization of lettuce growing on a local level. Thus the objective of this work was to assess lettuce yield and nitrate production and accumulation as function of the mineral Nitrogen supply and organic fertilization.

\section{MATERIAL AND METHODS}

The experiment was carried out in an area of commercial cultivation, in Esperança, Paraíba, on a Typical Quartz Psamment soil, in fallow for four years. The soil had the following chemical characteristics at the $0-20 \mathrm{~cm}$ layer: $\mathrm{H}_{2} \mathrm{O}$ $\mathrm{pH}=5.92, \mathrm{P}=27.35 \mathrm{mg} \mathrm{dm}^{-3}, \mathrm{~K}=94.38$ $\mathrm{mg} \mathrm{dm}{ }^{-3}, \mathrm{Ca}=1.75 \mathrm{cmol} \mathrm{dm}^{-3}, \mathrm{Mg}=0.7$ cmol dm ${ }^{-3}, \mathrm{Na}=0.05 \mathrm{cmol} \mathrm{dm}^{-3}, \mathrm{H}+\mathrm{Al}$ $=0.83 \mathrm{cmol}_{\mathrm{c}} \mathrm{dm}^{-3}, \mathrm{Al}=0.0 \mathrm{cmol}_{\mathrm{c}} \mathrm{dm}^{-3}$, and organic matter $=8.11 \mathrm{~g} \mathrm{~kg}^{-1}$. The cattle manure used in this work had the following chemical composition: $\mathrm{N}=$ $7.35 \mathrm{~g} \mathrm{~kg}^{-1}, \mathrm{~S}=2.25 \mathrm{~g} \mathrm{~kg}^{-1}, \mathrm{~K}=4.37 \mathrm{~g}$ $\mathrm{kg}^{-1}, \mathrm{P}=1.76 \mathrm{~g} \mathrm{~kg}^{-1}, \mathrm{Ca}=0.70 \mathrm{~g} \mathrm{~kg}^{-1}$, $\mathrm{Mg}=0.47 \mathrm{~g} \mathrm{~kg}^{-1}, \mathrm{Na}=543.21 \mathrm{mg} \mathrm{kg}^{-1}$, $\mathrm{Fe}=111.78 \mathrm{mg} \mathrm{kg}^{-1}, \mathrm{~B}=19.15 \mathrm{mg} \mathrm{kg}^{-1}$, $\mathrm{Mn}=86.88 \mathrm{mg} \mathrm{kg}^{-1}, \mathrm{Zn}=24.3 \mathrm{mg} \mathrm{kg}^{-1}$, and $\mathrm{Cu}=124 \mathrm{mg} \mathrm{kg}^{-1}$.

The experimental design was completely randomized blocks, with four replications and eleven treatments: five doses of cattle manure $(30 ; 60 ; 90 ; 120$, and $150 \mathrm{t} \mathrm{ha}^{-1}$ ), five doses of Nitrogen supplied as urea $(30 ; 60 ; 90 ; 120$, and 150 $\mathrm{kg} \mathrm{ha}^{-1}$ ), and a control without fertilization. Blocks were split on time, every 15 days, aiming at reducing the concentration of work on the harvest, mainly due to nitrate analyses. $\mathrm{N}$ was applied as following: 1/3 10 days after transplanting (DAT), 1/3 20 DAT, and 1/3 25 DAT. $P$ and $\mathrm{K}$ doses were 56 and $42 \mathrm{~kg} \mathrm{ha}^{-1}$ of $\mathrm{P}_{2} \mathrm{O}_{5}$ and $\mathrm{K}_{2} \mathrm{O}$, respectively, according to the soil chemical analysis and fertilization recommendations for the State of Ceará (UFC, 1993). P and K sources were simple superphosphate and chloride potassium, respectively. All $\mathrm{P}$ was applied at the transplanting, while $\mathrm{K}$ followed the same schedule as $\mathrm{N}$. The dried cattle manure was applied seven days before transplanting. Treatments with manure did not receive any other nutrient supply.

Cultivar Elba (butterhead) was used because it is the most popular among local farmers. Seedlings were grown on a conventional seedbed, until having four to five permanent leaves (30 days), when they were transplanted. Experimental plots consisted of boxes measuring $1.8 \mathrm{~m}^{2}(1.20$ $\mathrm{x} 1.50 \mathrm{~m}$ ), in which plants were grown on $0.30 \times 0.30 \mathrm{~m}$ spacing. Only the six central plants in each plot were taken into consideration for evaluation. Plants placed close to the borders of boxes were disregarded. Weeds were controlled by hand-hoeing. Plants were irrigated daily and no pest or disease treatments were applied. Harvests were carried out at the end of the afternoon (around 17:00 h), 30 days after transplanting. Only fully grown plants, with commercial characteristics, were harvested. Harvested plants were wrapped in plastic bags and brought to the laboratory for analyses. Plant total (PTY) and commercial yield (PCY), number of leaves per plant (NLP), and the nitrate content on roots, stems and leaves were evaluated. Nitrate contents were determined using the salicylic acid method (Cataldo et al., 1975), with modifications (Pôrto, 2006). Based on the dry matter content of the different parts of the plant (data not presented), nitrate contents in dry matter were converted to contents in fresh matter.

Data were submitted to the analysis of variance, splitting the quantitative effects of $\mathrm{N}$ and manure doses into regressions. Means for the control treatment, mineral N supply, and organic fertilization were compared using the Tukey test, at $5 \%$ probability. All statistical analyses were performed using the software SAEG, version 8.0 (SAEG, 2000).

\section{RESULTS AND DISCUSSION}

Plant total (PTY) and commercial yield (PCY) both for mineral Nitrogen supply and organic fertilization, within the dose interval used (30 to 150 ), had intersection points between the two adjusted models. Thus, we can state that, at these points, namely 63.7 (PTY) and 45.0 (PCY) $\left(\mathrm{kg} \mathrm{ha}^{-1}\right.$ and $\mathrm{t} \mathrm{ha}^{-1}$, for respectively mineral $\mathrm{N}$ and cattle manure), fertilization with either mineral $\mathrm{N}$ or cattle manure resulted in similar PTY and PCY (Figure 1). The $\mathrm{N}$ fertilization dose recommended for growing lettuce in soil fertility classes similar to the present experimental conditions is 30 (CEFSPE, 1998) or $40 \mathrm{~kg} \mathrm{ha}^{-1}$ (CEFSBA, 1989; UFC, 1993). Therefore, on soils of sandy texture, with low contents of organic matter, such as the soil presently used, $\mathrm{N}$ mineral fertilization can be fully replaced by organic fertilization using cattle manure.

PTY and PCY as affected by the mineral $\mathrm{N}$ supply fitted in a quadratic model, in which the doses 94.5 and 95.7 $\mathrm{kg} \mathrm{ha}^{-1}$ corresponded to respectively the highest PTY (381.9 $\left.\mathrm{g} \mathrm{plant}^{-1}\right)$ and PCY (321.6 g plant $^{-1}$ ) (Figure 1). Quadratic effect of increasing $\mathrm{N}$ doses $(0$ to $180 \mathrm{~kg}$ $\mathrm{ha}^{-1}$ of $\mathrm{N}$, in topdressing, in addition to the dose applied by the producer, $60 \mathrm{~kg} \mathrm{ha}^{-1}$ ), on PTY and PCY were also observed by Resende et al. (2005), on iceberg (crisphead) lettuce, cultivar Raider. Nevertheless, the doses reported by these authors (146.9 and $149.1 \mathrm{~kg} \mathrm{ha}^{-1}$ of N, to PTY and PCY, respectively) as the responsible for highest PTY and PCY (763.2 and $450.1 \mathrm{~g} \mathrm{plant}^{-1}$, respectively), were much higher than those currently found in this work. This divergence is likely to be related to different edaphoclimatic conditions between the experimental sites of both studies, as well as to different nutritional needs of the 
studied cultivars. $\mathrm{N}$ and $\mathrm{K}$ demands in iceberg lettuce are higher than in butterhead and crisp leaf cultivars.

PTY and PCY, where organic fertilization was used, fitted into a linear model. Therefore, the highest PTY (523.9 g plant $\left.^{-1}\right)$ and PCY $\left(449,48\right.$ g plant $\left.^{-1}\right)$ were observed at the highest manure doses (Figure 1). These results differ from what was reported by Yuri et al. (2004), who, in iceberg lettuce, cultivar Raider, observed quadratic effects of the organic fertilization ( 0 to $\left.80 \mathrm{t} \mathrm{ha}^{-1}\right)$ on yield. Yuri et al. (2004) obtained maximum PTY and PCY of respectively 914,2 and 634,3 g plant $^{-1}$, using 59,2 and 56,1 tha $^{-1}$ of organic compost. In the present work, we observed that organic fertilization resulted in higher increments in yield than urea (Figure 1), which stresses the largely documented impact of organic matter over lettuce yield (Santos et al., 2001; Villas Bôas et al., 2004; Yuri et al., 2004; Souza et al., 2005). It should be considered that organic matter contributes not only with nutrient supply to plants, but it also improves most of the physical soil characteristics (Santos et al., 2001), mainly on sandy soils as the one used in this experiment.

Nitrate content on roots, stems, and leaves increased linearly with Nitrogen and manure application. In roots, the nitrate content ( $\mathrm{mg} \mathrm{kg}^{-1}$ of fresh matter) reached 93.96 (mineral Nitrogen supply (MNS)) and 65.09 (organic fertilization (OF)); in stems, it went up to $183.45 \mathrm{MNS}$ and 98.22 OF; and, in leaves, $121.98 \mathrm{MNS}$ and 75.62 OF (Figure 2). Nitrate content in roots and stems are below those observed by Cometti et al. (2004) in organic (20 t ha ${ }^{-1}$ of cattle and poultry manure) and conventional grown lettuce $\left(300 \mathrm{~kg} \mathrm{ha}^{-1}\right.$ of the formula 4-14-8, in addition to manure). Nitrate content in leaves is also below previous reports for lettuce fertilized with several doses of mineral $\mathrm{N}$ and organic manure (Castro \& Ferraz Júnior, 1998; Benini et al., 2002; Krohn et al., 2003; Cometti et al., 2004; Mantovani et al., 2005). The relatively low nitrate contents reported here are likely to be related to the environmental conditions of this work, especially high luminosity and temperature, as well as to the harvesting hour (around 17:00 h), which contribute to reducing nitrate accumulation by plants (Marschner, 1995; Krohn et al., 2003; Faquin \& Andrade, 2004). Mineral Nitrogen fertilization resulted in higher nitrate content in plants than those observed when organic fertilization was used, in all

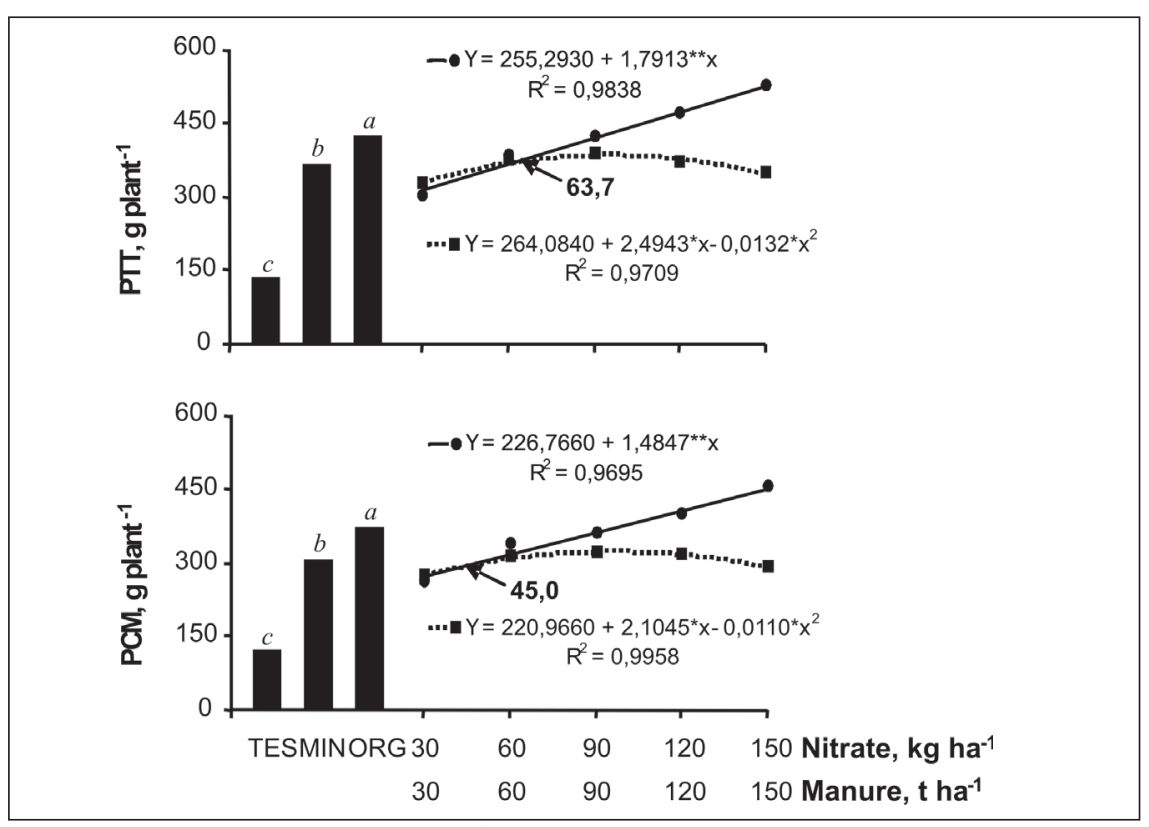

Figure 1. Plant total $\left(\mathrm{PTY}=\mathrm{PTT}, \mathrm{g}_{\text {plant }}{ }^{-1}\right)$ and commercial yield $\left(\mathrm{PCY}=\mathrm{PCM}, \mathrm{g}\right.$ plant $\left.^{-1}\right)$ of lettuce as affected by the mineral N supply (dotted line) and organic fertilization (bold line) (Produção total (PTT) e comercial (PCM) por planta de alface em função do fornecimento de nitrogênio mineral (linha pontilhada) e da adubação orgânica (linha cheia). Areia, UFPB-CCA, 2006.

****:significant at $\mathrm{p}<0.05$ and $\mathrm{p}<0.01$, respectively, t test $(* * * *$ significativo a $\mathrm{p}<0,05 \mathrm{e} \mathrm{p}<0,01$, respectivamente, pelo teste t). TES: PTY and PCY means in the control treatment (médias de PTT e PCM da testemunha); MIN: PTY and PCY means in treatments with mineral N supply (médias de adubação mineral dos tratamentos que receberam N mineral); ORG: PTY and PCY means in treatments with organic fertilization (médias de PTT e PCM dos tratamentos com adubação orgânica); esterco: manure; Nitrogênio: Nitrogen. Means followed by the same letter did not differ significantly from each other by the Tukey test, $\mathrm{p}<0.05$ (médias seguidas de mesma letra não diferem significativamente entre si pelo teste de Tukey, $\mathrm{p}<0,05$ ).

lettuce parts (Figure 2), with the highest values in stems and the smallest in roots. These results corroborate those of Cometti et al. (2004), who also observed that the conventional cultivation using soluble fertilizers tended to result in higher nitrate accumulation in lettuce than the organic production system. These authors also observed the highest nitrate contents in stems, raising the hypothesis that stems refrain nitrate accumulation in leaves.

Nitrate accumulation by plants is observed when plant Nitrogen uptake exceeds the assimilation capacity. The surplus of $\mathrm{N}$ inside the plant is then stored as nitrate in the cell vacuoles (Marschner, 1995). Thus, the highest nitrate concentration in plants observed when $\mathrm{N}$ was supplied using a mineral source compared to the organic fertilization is probably due to the prompt $\mathrm{N}$ availability in soluble fertilizers in the first, causing $\mathrm{N}$ abundance in the soil solution, in opposition to the slow nutrient release by the latter (Santos et al., 2001). However, it is important to mention that even the highest leaf nitrate content observed here is far below the limit prescribed by the European Union (3.500 to $4.500 \mathrm{mg} \mathrm{kg}^{-1}$ of fresh matter) (van der Boon et al., 1990). Considering the top nitrate contents observed in this work to the maximum limit of daily consumption recommended for human beings (3.6 mg kg-1 of live weight) (Escoín-Peña et al., 1998), a 70 kgperson would need 2.1 and $3.4 \mathrm{~kg}$ of lettuce cultivated with mineral $\mathrm{N}$ supply and organic fertilization, respectively, to reach the limit, not considering the use of other nitrate sources. Therefore, we can assume that nitrate contents in lettuce grown under these conditions do not jeopardize human healthy.

We observed that the use of organic fertilization resulted in higher lettuce yield than $\mathrm{N}$ supplied from a mineral source. Moreover, $\mathrm{N}$ mineral supply could be fully replaced by organic fertilization without compromising yield. Organic fertilization resulted also in significant lower nitrate content than what was observed for $\mathrm{N}$ mineral in all lettuce parts. Nevertheless, the highest leaf nitrate content observed was below the risk limit for human health. 


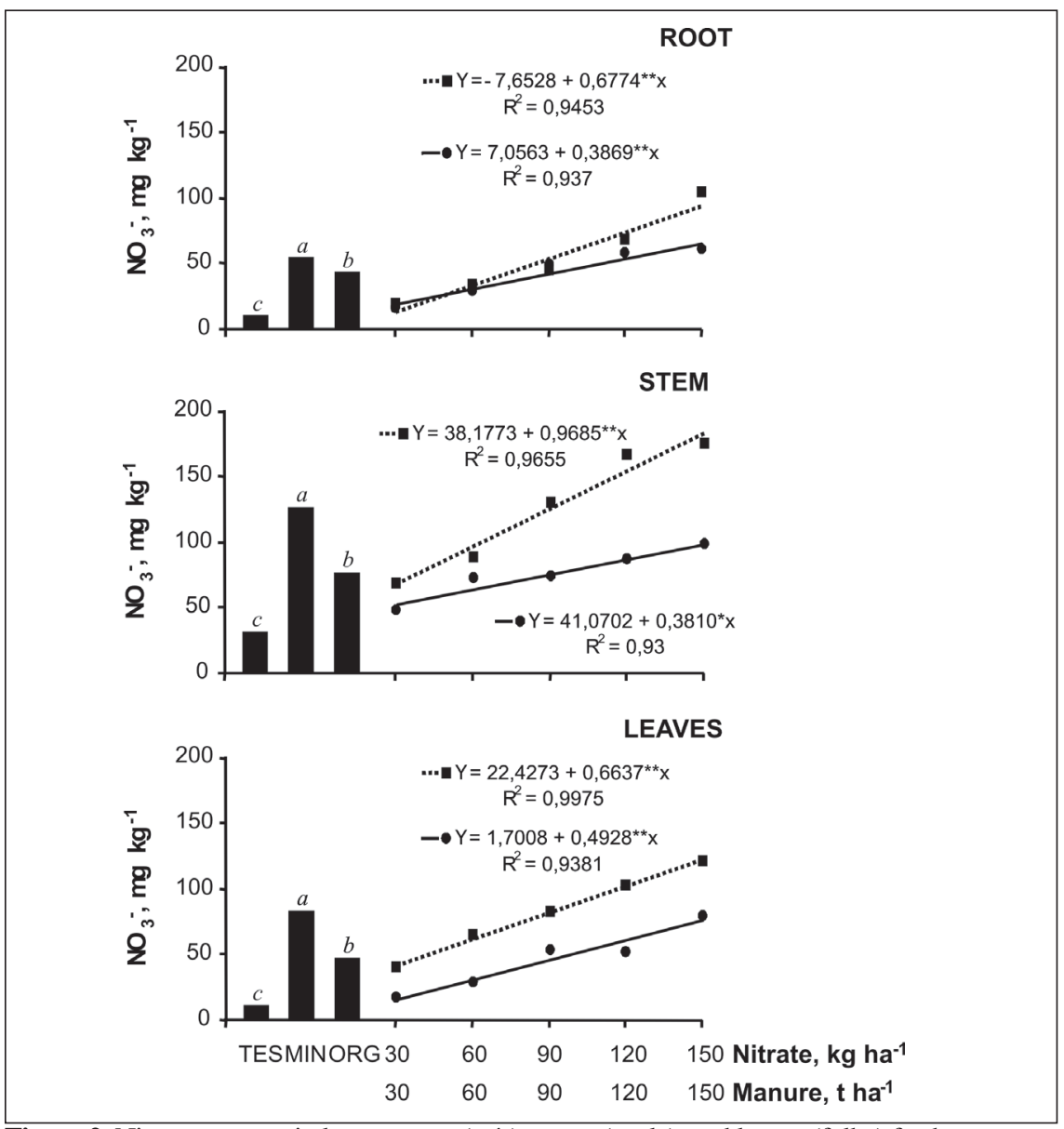

Figure 2. Nitrate contents in lettuce roots (raíz), stems (caule), and leaves (folha) fresh matter, as affected by the mineral $\mathrm{N}$ supply (dotted line) and organic fertilization (bold line) (teores de nitrato na massa fresca de raízes, caules e folhas da alface, em função do fornecimento de nitrogênio mineral (linha pontilhada) e da adubação orgânica (linha cheia). Areia, UFPB-CCA, 2006. *****significant at $\mathrm{p}<0.05$ and $\mathrm{p}<0.01$, respectively, t test $(* * * *$ significativo a $\mathrm{p}<0,05$ e $\mathrm{p}<0,01$, respectivamente, pelo teste t). TES: PTY and PCY means in the control treatment (médias de PTT e PCM da testemunha); MIN: PTY and PCY means in treatments with mineral N supply (médias de adubação mineral dos tratamentos que receberam N mineral); ORG: PTY and PCY means in treatments with organic fertilization (médias de PTT e PCM dos tratamentos com adubação orgânica); Nitrogênio: Nitrogen; Esterco: manure. Means followed by the same letter did not differ significantly from each other by the Tukey test, $\mathrm{p}<0.05$ (médias seguidas de mesma letra não diferem significativamente entre si pelo teste de Tukey, $\mathrm{p}<0,05)$.

\section{ACKNOWLEDGEMENTS}

Authors thank Mr. José Arimatéia da Silva and family for making the area to carry out this experiment available. Mônica L Pôrto thanks CAPES for the M.Sc. scholarship, and Jailson do C Alves and Jandeilson A de Arruda thank CNPq for respectively a M.Sc. and a Scientific Initiation scholarships.

\section{REFERENCES}

BENINNI ERY; TAKAHASHI HW; NEVES CSVJ; FONSECA ICB. 2002. Teor de nitrato em alface cultivada em sistemas hidropônico e convencional. Horticultura Brasileira 20: 183-186.
COMETTI NN; MATIAS GCS; ZONTAE; MARY W; FERNANDES MS. 2004. Compostos nitrogenados e açúcares solúveis em tecidos de alface orgânica, hidropônica e convencional. Horticultura Brasileira 22: 748-753.

ESCOÍN-PENA MC; IBANEZ MAC; SANTAMARTA AA; LAZARO RC. 1998. Contenido de nitrato en lechugas y espinacas frescas. Alimentaria 298: 37-41.

FAQUIN V; ANDRADE AT. 2004. Nutrição mineral e diagnose do estado nutricional de hortaliças. Lavras: UFLA/FAEPE. 88p.

FILGUEIRA FAR. 2003. Novo manual de olericultura: agrotecnologia moderna na produção de hortaliças. Viçosa: UFV. 412p.

KROHN NG; MISSIO RF; ORTOLAN ML; STEINMACHER DA; LOPES MC. 2003. Teores de nitrato em folhas de alface em função do horário de coleta e do tipo de folha amostrada. Horticultura Brasileira 21: 216-219.

MANTOVANI JR; FERREIRA ME; CRUZ MCP. 2005. Produção da alface e acúmulo de nitrato em função da adubação nitrogenada. Horticultura Brasileira 23: 758-762.

MARSCHNER H. 1995. Mineral nutrition of higher plant. New York: Academic Press. 889p.

PÔRTO ML. 2006. Produção, estado nutricional $e$ acúmulo de nitrato em plantas de alface submetidas à adubação nitrogenada e orgânica. 2006. Areia: UFPB-CCA. 66f. (Tese mestrado)

RESENDE GM; ALVARENGA MAR; YURI JE; MOTA JH; SOUZA RJ; RODRIGUES JÚNIOR JC. 2005. Produtividade e qualidade pós-colheita da alface americana em função de doses de nitrogênio e molibdênio. Horticultura Brasileira 23: 976-981.

SAEG. 2000. Sistema para Análises Estatísticas. Versão 8.0. Viçosa: Fundação Arthur Bernardes.

SANTOS RHS; SILVA F; CASALI VWD; CONDÉ AR. 2001. Efeito residual da adubação com composto orgânico sobre o crescimento e produção de alface. Pesquisa Agropecuária Brasileira 36: 1395-1398.

SOUZA PA; NEGREIROS MZ; MENEZES JB; BEZERRA NETO F; SOUZA GLFM; CARNEIRO CR; QUEIROGA RCF. 2005. Características químicas de folhas de alface cultivada sob efeito residual da adubação com composto orgânico. Horticultura Brasileira 23: 754-757.

UFC. Universidade Federal do Ceará. 1993. Recomendações de adubação e calagem para o Estado do Ceará. Fortaleza: Imprensa Universitária. 247p.

van der BOON J; STEENHUIZEN JW; STEINGROVER EG. 1990. Growth and nitrate concentration of lettuce as affected by Nitrogen and chloride concentration, $\mathrm{NH}_{4}{ }^{+} / \mathrm{NO}_{3}^{-}$ratio, and temperature of the recirculating nutrient solution. Journal of Hoticultural Science 3: 309-321.

VILLAS BÔAS RL; PASSOS JC; FERNANDES M; BÜLL LT; CEZAR VRS; GOTO R. 2004. Efeito de doses e tipos de compostos orgânicos na produção de alface em dois solos sob ambiente protegido. Horticultura Brasileira 22: 28-34.

YURI JE; RESENDE GM; RODRIGUES JÚNIOR JC; MOTA JH; SOUZA RJ. 2004. Efeito de composto orgânico sobre a produção e características comerciais de alface americana. Horticultura Brasileira 22: 127-130. 